\title{
Correction to: Using Gilles Lipovetsky Concepts to Frame Leisure Studies in the Hypermodern Age
}

\author{
Romain Roult $^{1} \mathbb{D} \cdot$ Gilles Pronovost $^{1} \cdot$ Frédéric Martineau $^{1}$
}

Published online: 30 August 2021

(c) Springer Nature Switzerland AG 2021

\section{Correction to: International Journal of the Sociology of Leisure https://doi.org/10.1007/s41978-021-00090-7}

The corresponding author noticed a minor error in the in-text citation for reference of Blackshaw (2013) on the page 8 in his published paper. The correct in-text citation is Blackshaw (2013) and not (Blackshaw, 2013, p. 84).

Publisher's Note Springer Nature remains neutral with regard to jurisdictional claims in published maps and institutional affiliations.

The original article can be found online at https://doi.org/10.1007/s41978-021-00090-7.

Romain Roult

romain.roult@uqtr.ca

1 Department of Leisure, Culture and Tourism Studies, Université du Québec À Trois-Rivières, 3351 Boul. Des Forges, CP.500, Trois-Rivieres, QC G9A 5H7, Canada 